\title{
AGRICULTURE, LAW, AND THE STATE
} Matthew Canfield, Amy J. Cohen and Michael Fakhri

Agriculture is the domestication of plants and animals. Today, the most pressing political questions about agriculture are questions about the production and distribution of food. Food, in turn, is a boundary object. It is both a market commodity and a basic need, straddling the boundaries of the public and private. Contests over food thus serve as key sites for socio-legal inquiry about national and international law and institutions, for example, how states and nonstate actors construct legal rules that govern market exchange, allocate the world's natural resources, regulate safety and risk, and articulate ideals of economic and social development and the common good.

In this entry, we briefly trace how states and other actors have used legal rules and institutions to govern the provisioning of agriculture-based food and to shape national and global power since World War II. In sum, from the 1950s to around the 1980s, governments used law to stabilize and protect (select) domestic markets. From the 1980s to 2008, by contrast, powerful nations and international organizations instead prioritized a legal regime designed to maximize global trade. Since the food crisis of 2006-2008 - when the prices of staple cereals skyrocketed in response to rising energy prices and competition for agricultural land - conflicts over global agriculture have led development planners to ask how agricultural trade can serve the needs of the people who lack food security including by promoting a market-led smallholder-driven agricultural sector in the Global South. We suggest that today the increasing global integration of food supply chains alongside changes in biotechnology have produced new sources of legal and political authority and new struggles over the future of agricultural accumulation.

From the 1950s until 2008, development planners largely neglected agricultural development. Third World governments and international institutions alike shifted resources away from agriculture towards industrialization. In the 1950s, many former colonies exported a small number of primary commodities; as such, they were particularly vulnerable to fluctuating world prices in ways that followed imperial trade patterns. The question that Third World governments put to each other was whether they could redistribute global power and wealth towards the world's poorest countries by creating their own industrial sectors.

In the West, a legal regime of state intervention facilitated this effort at industrial transformation. When, after World War II, the Bretton Woods international monetary system tied world currencies to the U.S. dollar, the United States created an export subsidy when it sold wheat abroad in negotiated prices. It cleverly named this policy 'food aid'. Between 1956 and 1965, US food aid comprised a stunning one-third of world trade in wheat. Food aid enabled the United 
States to protect domestic producers while cultivating Cold War allies among newly independent countries. Many of these countries were agrarian societies, self-sufficient in food grains, but increasingly imported subsidized grains to provide people cheap food and encourage the growth of industrial labour. Along with food aid, the US also encouraged these countries to adopt new 'Green Revolution' technologies - high-input practices of industrialized farming - meant to boost production and ameliorate hunger. However, in many places, the Green Revolution served to exacerbate rural inequalities, while also creating a global market for Western-based agrochemical firms.

During this period, both the Third World and First World constructed and used multilateral trade institutions to work out the relationships among national sovereignty, food security, and markets. These institutions included the International Trade Organization, the United Nations Conference on Trade and Development (UNCTAD), the Global Agreement on Trade and Tariffs (GATT) (which excluded agricultural products from trade liberalization), the Food and Agriculture Organization (FAO), and various international commodity agreements. This global legal regime facilitated the interlocking of national markets through policies of supply management that typically included production controls, price supports, and import/export subsidies. It ended, however, in crisis when, in 1972-1973, the Soviet Union purchased 30 million metric tons of grain from the US (three quarters of all grain on the world market) to feed its people. This sale, along with spikes in international oil prices, meant that the price of wheat more than tripled, compelling developing countries dependent on imports to borrow money from banks. And because in many developing economies, urbanization outpaced industrialization, the number of people who needed to purchase imported wheat outnumbered those who could afford to do so. 'Suddenly', Harriet Friedmann recounts, 'billions of people were defined as "food insecure".

In the 1980s and 1990s, powerful states, international organizations, and agribusiness corporations used these international institutions to reconfigure agriculture as a question of trade liberalization. Developing countries wanted a regime that made it easier for them to export their agricultural goods to developed country markets. Agribusiness corporations in the West, which had benefited from decades of government subsidies, had vastly increased in power and transnational scale; by now, they wanted a regime that prioritized exporting products from Western markets to the rest of the world. European countries which had adopted protectionist policies had amassed their own surpluses and began to compete intensely with the United States for export markets. As competition amongst more powerful countries increased, export subsidies could no longer masquerade as aid.

In 1986, the US, the European Community, and other wheat exporting countries began negotiations to include agriculture within formal legal trade agreements that culminated in 1994 with the World Trade Organization (WTO) Agreement on Agriculture. Food security, the United States argued in these negotiations, is 'best provided through a smooth-functioning world market'. After the 1970s, powerful states no longer described food security as a moral imperative to provide food for their citizens but rather reinterpreted it within a globalizing market-based framework.

A new international legal regime replaced state intervention with neoclassical economics. Countries in the West stressed technological innovation coupled with strong protection for intellectual property rights such as patented seeds and other forms of biotechnology. For developing countries, conditions imposed on loans in the 1980s and 1990s required governments to limit agricultural subsidies and increase interest rates. These 'structural adjustments' had disastrous effects on developing countries. Rather than smooth-functioning markets, the first decade of the $20^{\text {th }}$ century witnessed riots in numerous countries around the world that reflected food 
shortages and price spikes - recurring instability precipitated not only by climate change but also by global markets that facilitated food price speculation and the effect of the global biofuel industry on food prices.

This 2006-2008 global food crisis challenged the reigning liberalizing ideology for global food provisioning. Transnational social movements, such as the La Via Campesina and the International Planning Committee for Food Sovereignty, demanded more democratic forms of global food and agricultural regulation. Their relentless pressure since the signing of the Agreement on Agriculture in 1994 led to the reform of the UN Committee on World Food Security (CFS) in 2008 , which was transformed from a largely ineffectual intergovernmental body into an innovative, multi-actor platform that describes itself as the "the foremost inclusive international and intergovernmental platform for all stakeholders to work together to ensure food security and nutrition for all'. The CFS has been hailed by observers as a potential exemplar for participatory global governance due to its inclusion of social movements in decision-making processes. Similarly, across the global food chain, multi-stakeholder governance arenas have proliferated.Yet questions remain about whether these new forms will democratise food chain governance and improve the livelihoods and welfare of small farmers in developing countries.

Consider, for example, 'value chain agriculture' - an increasingly dominant multi-stakeholder development model meant to alleviate rural poverty through creating profitable smallholderdriven agricultural economies in countries throughout the Global South. In 2008, the World Bank catalysed this paradigm shift when it proposed that small farmers too can learn to participate in 'the "new agriculture" of high-value products' - a marked change in its policy.

Since 2008, the emergent dominant political and legal ideal is neither state-managed agriculture nor free trade focused on the liberalization of national markets as much as a 'third way' where global value chain proponents and policymakers focus on lead firms as much as nations. They consider, for example, how agribusiness firms operate as governance bodies by setting quality and performance metrics, distributing profit and risk, and creating patterns of access and exclusion so that new sources of value are both created and shared. In this regime, critical questions of law and regulation often emerge less through either state intervention or deregulation, but rather through new voluntary or contractual codes of conduct, third-party certification schemes, and other forms of non-state private standards. Non-governmental organizations setting standards for 'good' seafood or 'good' lumber and paper products are examples of this new type of agricultural governance.

Conflicts around the production and provisioning of food have thus generated a contested legal landscape, with competing and overlapping regulatory networks, including those created by social movements and agribusiness corporations as well as by international organizations and states, all of which now seek to influence the governance of global agriculture. These networks illustrate a partial denationalisation of authority as a range of actors struggle to set rules and standards over investment, markets, and food safety. Whether these new forms of governance will prove democratic, equitable, or collaborative is a question for future empirical research. For example, one arena of transnational conflict is over the regulation of agricultural biotechnology. Disputes about the safety of genetically modified organisms (GMOs) and other technologies have grown increasingly acute as powerful global actors, including agribusiness corporations, propose them as a solution to climate change. While the United States has taken a permissive approach to biotechnology regulation, Europeans and much of the rest of the world have taken a much more precautionary approach, prompting prolonged conflicts in both the World Trade Organization and the European Union. These conflicts reveal not only how culturally contingent understandings of scientific authority shape regulation, but also the potential limits of global cooperation. 


\section{Canfield, A.J. Cohen, M. Fakhri}

This entry has traced how conflicts over agriculture and food have long served to construct but also to challenge dominant legal rules of exchange, development, and distribution among humans. Today, these conflicts are increasingly about human relationships with the natural world. Agriculture presently contributes almost one-third of total global greenhouse gas emissions. This is a result of a century pursuing highly mechanized industrial agriculture and the spread of an increasingly meat-heavy diet. The future of agriculture and food now cannot be analysed apart from climate change and sustainable economic development. While powerful actors continue to promote industrial agricultural development, insurgent social movements have promoted ecological forms of agricultural production. Ultimately, the struggle between these competing models will be resolved through regulatory arrangements that have profound impacts for the future of transnational governance and law.

\section{Further readings}

Canfield, Matthew. 2018. 'Compromised Collaborations: Food, Fuel, and Power in Transnational Food Security Governance’. Transnational Legal Theory 9 (3-4): 272-287. https://doi.org/10.1080/20414 005.2019 .1571772

Cohen, Amy J. 2015. 'The Law and Political Economy of Contemporary Food: Some Reflections on the Local and the Small'. Law and Contemporary Problems 78: 101-145.

Fakhri, Michael. 2014. Sugar and the Making of International Trade. Cambridge and New York: Cambridge University Press.

Friedmann, Harriet.1993. 'The Political Economy of Food:A Global Crisis'. New Left Review 197: 29-57. 